\title{
Interaksi Arsitek dan Teknik Sipil Dalam Perencanaan Pulau Reklamasi, Studi Kasus Centrepoint of Indonesia, Makassar
}

\author{
The Interactions of Architects and Civil Engineers in the Design Process of \\ Reclamation Island: Centrepoint of Indonesia Case Study, Makassar
}

\author{
Adecar Nugroho ${ }^{1}$, Weni Sihombing ${ }^{2}$, Anggita Krisnandini ${ }^{3}$ \\ ${ }^{1}$ Geotechnical Engineering Departement, PT. Witteveen Bos Indonesia \\ ${ }^{2}$ Coastal and water management Department, PT. Witteveen Bos Indoneisia \\ ${ }^{3}$ Design and visualization Department, PT. Witteveen Bos Indonesia
}

Email: adecar.nugroho@witteveenbos.com

\begin{abstract}
Abstrak
Perencanaan desain arsitektur selalu berjalan secara simultan dan saling mendukung dengan teknik sipil. Dalam proses konstruksi, pendekatan integrated design dilakukan dengan menerapkan teknik design loops. Teknik ini digunakan sebagai alternatif alur desain yang linear di mana proses interaksi dari beberapa disiplin akan sangat minim. Namun pada kenyataannya untuk mengidentifikasi permasalahan dalam proyek dari sisi sipil dan arsitektur serta solusi yang dapat diterapkan dibutuhkan interaksi yang sangat terintegrasi. Konsep integrated design menjadi acuan dalam proses perencanaan layout dari Centrepoint of Indonesia di Kota Makassar. Area ini berlokasi di pesirir laut sehingga didominasi oleh area waterfront. Hasil studi geografis di sekitar tapak menunjukan adanya beberapa karakteristik lahan yang perlu diberikan perlakuan khusus terkait manajemen air dan teknik kelautan. Berdasarkan proses design loop ini, dilakukan perubahan layout yang menjadi keluaran pertama dari perencanaan zoning arsitektur, di mana hasil pemodelan gelombang menunjukan adanya gelombang ekstim yang datang dari sisi barat sehingga membutuhkan proteksi yang lebih tinggi dari sisi tersebut. Perubahan ini tidak langsung menggugurkan nilai perencanaan yang di usung oleh pihak arsitek namun malah mempertajamnya tanpa mengesampingkan faktor keamanan yang diusung pihak perencana teknik sipil. Sebagai contoh lain, hasil pemodelan hidrodinamika mengindikasikan bahwa dibutuhkan kanal di antara pulau untuk meningkatkan kualitas air di sekitar pulau pulau reklamasi, adanya kanal-kanal di area site, menimbulkan suatu konsep arsitektur yaitu waterfront design dengan elemen utama lansekap yaitu promenade. Konsep desain lansekap tersebut menciptakan elemen estetika yang dapat meningkatkan added-value bagi properti di area ini.
\end{abstract}

Kata kunci: Integrated design, design loops, waterfront, added value.

\section{PENDAHULUAN}

Intergrated design adalah istilah pendekatan yang digunakan dalam proses desain konstruksi yang bertujuan untuk meraih sustainability value. Baik dari segi estetika desain, struktur dan material, biaya hingga nilai jual.

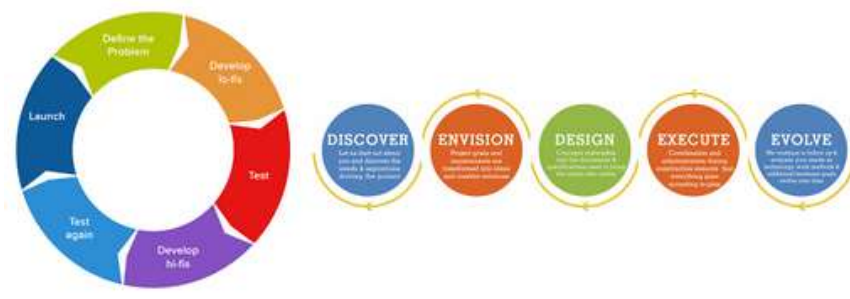

Gambar 1 Tahap design. Sumber: Witteveen+bos 


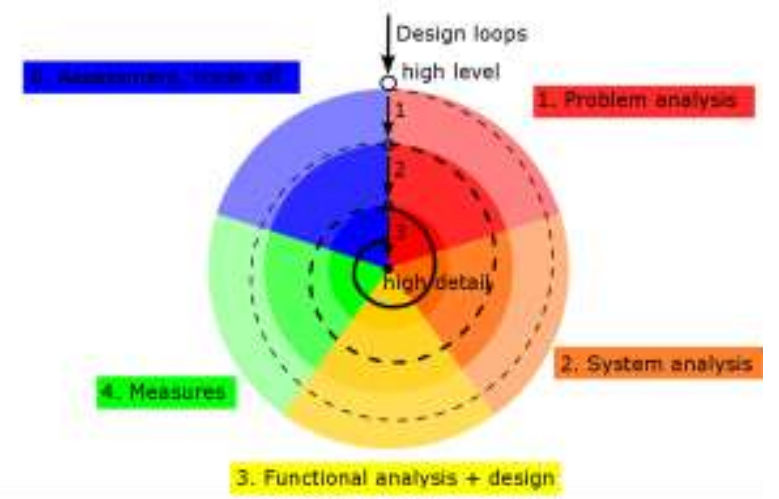

Gambar 2 Tahap desain dan skematik design loop. Sumber: Witteveen+Bos

Dalam pendekatan ini terdapat teknik yang dapat digunakan untuk menghasilkan output design yang sesuai dengan target berkelanjutan . Teknik tersebut dikenal dengan design loops. Teknik ini digunakan dalam proses konstruksi untuk mengidentifikasi kekuatan dan kekurangan dari suatu proyek dilihat dari berbagai aspek. Teknik design loops adalah alternative bagi proses desain linear flow dimana dua disiplin berbeda (contohnya arsitektur dan sipil) berinteraksi, bertukar traits dan bersama menemukan solusi baru terhadap permasalahan tersebut.

Salah satu nilai yang ingin di angkat dari sisi arsitektur pada pulau reklamasi adalah Promedane. Promenade adalah area untuk berjalan atau mengendarai sepeda sebagai upaya relaksasi atau sebagai display dan parade. Kata promenade sendiri memiliki arti jalan setapak atau jalan pedestrian. Umumnya berada di taman atau di pinggir pantai dan sungai. Promenade di sepanjang pesisir pantai dikenal dengan nama Waterfront Promenade. (Kristiánová, 2018)

Di samping promedane, konsep ruang terbuka hijau juga di angkat untuk menanggalkan pandangan umum yang cenderung buruk padaproyek reklamasi di Indonesia pada umumnya. Ruang terbuka hijau (RTH) adalah area dalam perencanaan bangunan yang digunakan sebagai area terbuka hijau. RTH elemen penting bagi keseimbangan lingkungan. Mulai dari ruang penyerapan air tanah, ruang buffer polusi udara hingga ruang bagi keanekaragaman hayati. Hal ini sesuai dengan perkembangan sustainable building development, aspek dari Sustainable Development Goals yang diterapkan oleh berbagai Negara di dunia termasuk Indonesia.

Berdasarkan Permen PU No. 5 Tahun 2008 mengenai Kebutuhan Luasan RTH, Pemerintah Indonesia menerapkan persentase dari RTH dalam perencanaan bangunan yaitu minimal $30 \%$ dari total luas area perencanaan. Teknik desain loops kemudian di terapkan pada proyek Center Point Indonesia Makassar bertujuan untuk menemukan kekuatan dan kekurangan dari desain. Pada tahapan perencanaan teknik sipil, dilakukan studi bathymetry, wave exposure dan water circulation pada area tersebut yang menitik beratkan pada keamanan pada masa konstruksi dan masa layan pulau reklamasi tersebut. Dua sisi perencanaan inilah yang akan di integrasikan agar menciptakan suatu rencana konstruksi yang memiliki nilai arsitektural dan keamanan yang tinggi.

\section{METODE}

Metode yang digunakan adalah metode kuantitatif-kualitatif. Dilakukan perbandingan data kuantitatif saat studi data geografis yang setelah itu dikaitkan dengan data kualitatif dari hasil pemodelan gelombang dan hidrodinamik. Akan tetapi dikarenakan perjanjian kerja sama antara pemberi kerja dan pihak konsultan, tidak semua data dapat dijabarkan untuk umum. Hal ini dikondisikan sedemikian sehingga di harapkan tidak mengurangi bobot dari penulisan karya tulis ini.

\section{PEMBAHASAN}

Dalam studi kasus proyek Centerpoint Indonesia Makassar, desain layout mengalami perubahan (5 tahap) berdasarkan studi bathymetry, wave exposure dan water circulation dari site. Dimana dalam lima tahap ini interaksi yang padat dan efisien antara perencana arsitektur, teknik sipil dan lingkungan terjadi. 


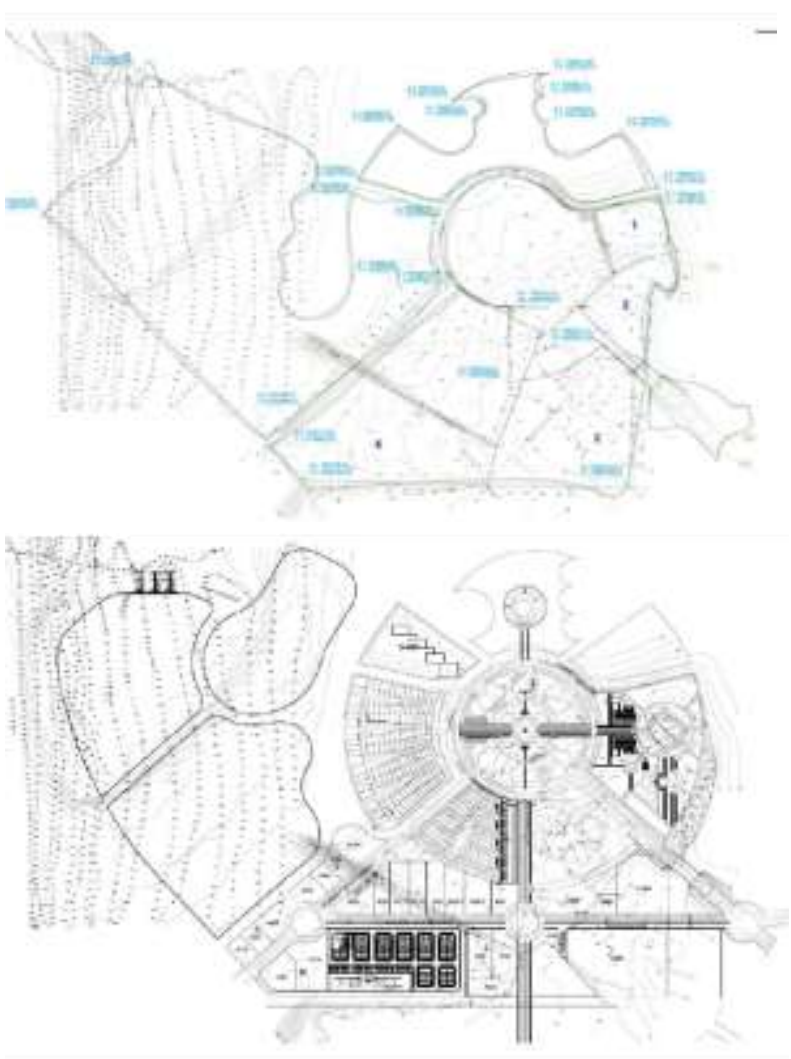

Gambar 3 Layout 1 (atas) dan Layout 5 (bawah)

Proses perubahan dari layout 1 menjadi layout 5 adalah berdasarkan beberapa faktor berikut:

1. kontur kedalamannya yang terjal dan dikombinasikan dengan gelombang ekstrim datang dari arah barat yang akan berdampak pada ketebalan material timbunan yang tinggi dan kemiringan lereng tanggul yang landai sehingga berdampak pada volume materialnya banyak. Di bagian barat kedalaman dari laut bertambah secara signifikan dari -6 m dibawah MSL sampai -20 m di bawah MSL. Hal ini akan mengakibatkan biaya konstruksi yang sangat tinggi, yang mana menjadi titik awal evaluasi dari perencanaan.

2. Definisi batas lahan yang mengalami perubahan ke arah darat juga berakibat pada kurangnya saleable area, sehingga perlu dilakukan adjustment di area lain untuk mencukupi kebutuhan RTH sesuai peraturan perundang-undangan

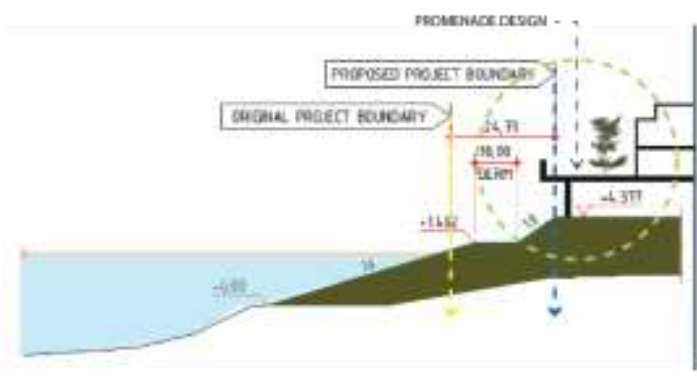

Gambar 4 Skematik Promenade.

3. Perubahan layout 1 ke 5 juga merupakan hasil adaptasi dari hasil hidrodinamika modeling yang menunjukan dibutuhkannya sirkulasi air yang baik di sekitar pulau. Sehingga bentuk pulau pun di sesuaikan dengan mengakomodasi kanal kanal pembatas antara pulau. Hal ini menjadi penting dimana saat sirkulasi air tidak lancar maka akan timbul bau yang tidak sedap (berasal dari aliran sungai Jongaya di selatan pulau) dan akan menurunkan nilai estetika dan manfaat dari daerah tersebut.
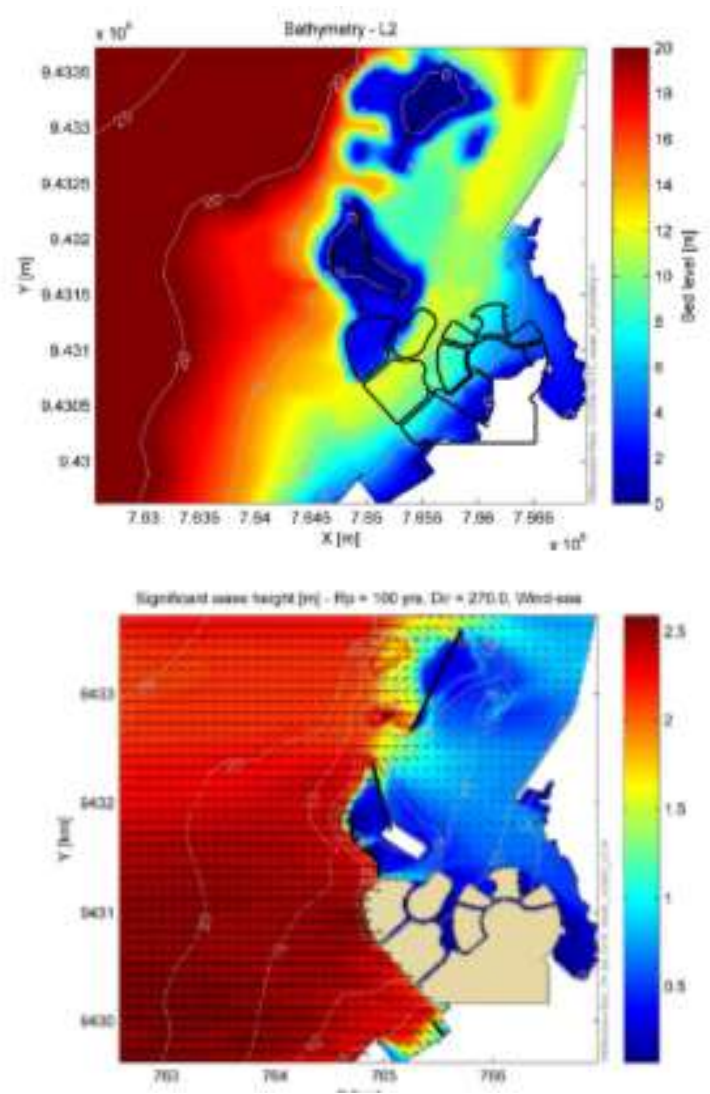

Gambar 5 Studi Bathymetry dan Wave Exposure 
4. water circulation perubahan layout, jongaya, beach

Terjadi perubahan layout dibagian selatan agar air dari kanal Jongaya (yang dianggap bermasalah water qualitynya) tidak sepenuhnya masuk ke timur reklamasi (Di timur reklamasi direncanakan ada pantai), sehingga dibuat kanal dibagian selatan pulau reklamasi. Dari hasil water quality model terlihat hanya $20 \%$ air dari Jongaya kanal yang mengalir ke timur reklamasi dan selebihnya dibuang langsung ke laut melalui kanal selatan.

Perubahan layout ini berdampak langsung terhadap perencanaan desain arsitektur. Layout tata ruang air dengan beberapa kanal di setiap pulau adalah solusi dari isu di lapangan tapi dapat juga menjadi tema utama desain arsitektur dari pulau ini sendiri. Pulau yang kemudian dipecah menjadi beberapa pulau yang lebih kecil, dibatasi oleh kanalkanal berfungsi untuk mengingkatkan kualitas sirkulasi air di dalam dan di sekitar pulau. Hal ini menjadi inspirasi bagi arsitek untuk menentukan zoning di dalam pulau tersebut.

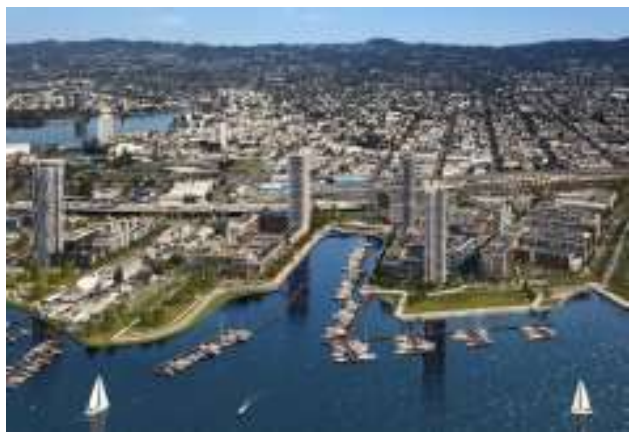

Gambar 6 Contoh Brooklyn Basin Waterfront di Oakland, AS (sumber: http://www.btcalameda.org/ brooklyn-basin-project-breaks-ground/)

Arsitektur dari lokasi yang berbatasan langsung dengan muka air ini dikenal dengan Coastal Architecture atau Arsitektur Pesisir. Dalam Arsitektur pesisir, dikenal garis pantai atau waterfront line. Umumnya pada waterfront line, diterapkan desain marina atau promenade yang menjadi ruang terbuka transisi batasan antara air laut dengan daratan. Desain promenade ini idealnya disesuaikan dengan bentuk terrain dan elevasi dari site.

Dengan melihat site yang memiliki karakteristik khusus, dapat diterapkan strategi desain promenade yang beragam dengan keunikan dan gaya tersendiri. Promenade juga dapat dijadikan sebagai elemen RTH area desain lansekap sehingga dapat melengkapi persyaratan dari peraturan RTH daerah.

Desain lansekap yang menarik dapat menjadi added value bagi nilai jual property pulau ini. Added value pertama adalah dalam meningkatnya kualitas lingkungan yang berkelanjutan dan estetika ruang dan kedua adalah dapat meningkatkan daya tarik calon pembeli atau investor.

\section{HASIL DAN KESIMPULAN}

Melihat proses dari perencanaan Center point Indonesia Makassar diketahui bahwa teknik design loop yang di gunakan telah membawa nilai tambah bagi perencanaan pulau reklamasi yang bersangkutan, sekaligus menjadi alasan timbulnya konsep baru dari sisi arsitektur.

Hasil studi bathymetry dan solusi dari segi durabilitas dan efektifitas struktur, menimbulkan layout baru yang lebih efektif terkait integrated design. Dari segi arsitektur, dengan adanya kanal dalam layout, konsep waterfront design menjadi konsep unik yang menjual.

Bentuk yang unik dari layout Center Point of Indonesia Makassar yang terlihat organik ini menunjukan adanya konsep form follow function dimana fungsi dari utilitas air menjadi konsep utama dan estetika dari arsitektur tersebut. Mengacu pada teori added value, estetika arsitektur adalah elemen penting bagi nilai jual suatu properti, begitu pula dengan kualitas lingkungan dari site (durabilitas, keberlanjutan lingkungan). Oleh karena itu, teknik desain loops antara aspek engineering 
dan arsitektur adalah tahap penting dalam perencanaan.

\section{DAFTAR PUSTAKA}

Kristiánová, K., 2018. Promenade as Landscape Architecture Strategy for Riverbanks of Small Danube Cities: Komárno and Štúrovo. Intech Open.

Luttik, J., 2000. The Value of Trees, Water and Open Space as Reflected by House Prices in the Netherlands.

Star, T., 2005. Gamuda offers vast expanse of green to home buyers. [Online] Available at: https://www.thestar.com.my/business/businessnews/2005/01/17/gamuda-offers-vast-expanse-ofgreen-to-home-buyers

[Accessed 11 2020].

Witteveen+Bos, 2015. Basis of Design report of Center point of Indonesia reclamation Makassar, Jakarta: s.n. 